\title{
Trombosis de la vena subclavia izquierda, síndrome de Paget-Schroetter
}

\author{
Thrombosis of the left subclavian vein, Paget-Schroetter syndrome
}

\author{
Luis Gerardo Domínguez Carrillo*
}

Citar como: Domínguez CLG. Trombosis de la vena subclavia izquierda, síndrome de PagetSchroetter. Acta Med GA. 2022; 20 (1): 101-102. https://dx.doi.org/10.35366/103568

Masculino de 20 años de edad, estudiante, practicante de fisiculturismo seis días/semana. Acude a consulta de rehabilitación por presentar dolor con intensidad 5/10 en escala visual analógica (EVA), y edema de extremidad torácica izquierda de 24 horas de evolución. Como antecedente menciona haber incrementado en los dos días previos carga importante en ejercicios de extremidades superiores. A la exploración dirigida, venas ingurgitadas en miembro torácico izquierdo, con edema suave sin signo de Godet con arcos de movilidad completos de hombro, codo, carpo y manos, fuerza muscular 5/5 en escala de Daniels para todos los músculos de extremidades superiores, reflejos osteotendinosos normales, pulsos y llenado capilar normal; como dato de interés, dolor moderado en brazo al efectuar elevación de miembro torácico izquierdo por arriba de la cabeza. Por las características atléticas del paciente, el esfuerzo realizado y la evolución aguda se efectúa diagnóstico presuntivo de trombosis de vena subclavia izquierda (síndrome de Paget-Schroetter). Se solicita ultrasonido, el cual lo confirma (Figuras 1 a 3). El paciente se derivó como urgencia a angiología y cirugía vascular.
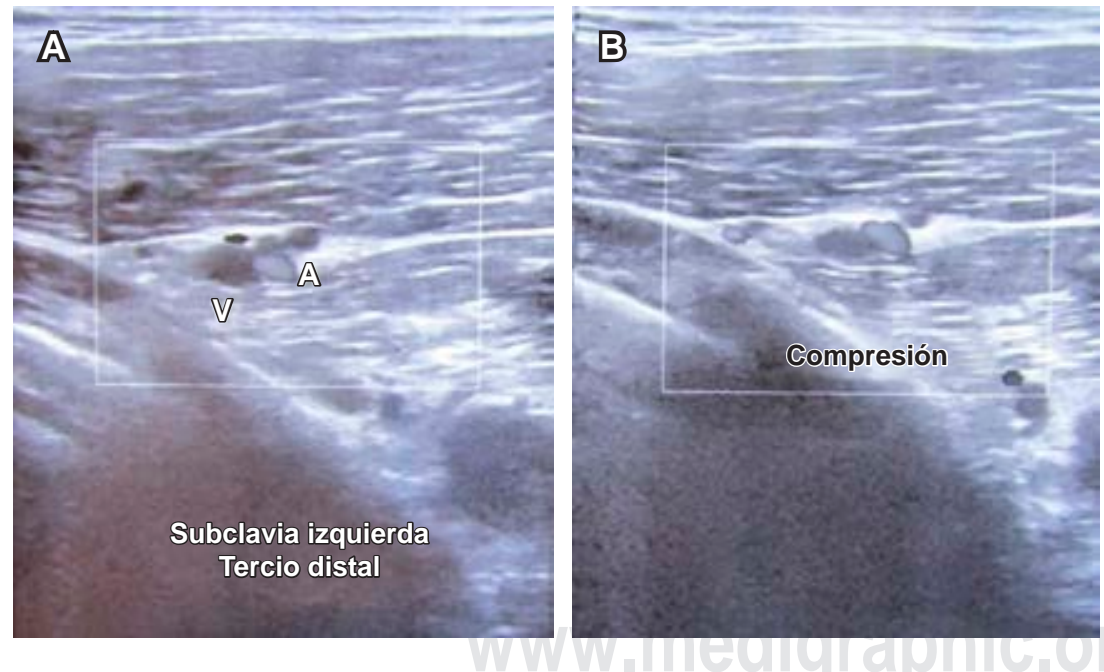

Figura 1:

Imágenes ecosonográficas sobre tercio distal de clavícula izquierda en las que se observan cortes transversales de arteria, vena subclavia en su tercio distal y vena con discreta imagen ecogénica en su luz vascular que no permite la saturación de color.

\footnotetext{
* Especialista en Medicina de Rehabilitación. Catedrático de la Facultad Aceptado: 03-08-2020. de Medicina de León, Universidad de Guanajuato. México.
} 
Figura 2:

Imágenes ecosonográficas abarcan los tres tercios de la vena subclavia y muestran: trayecto y calibre adecuados, discreta imagen ecogénica y ausencia de flujo al Doppler pulsado.
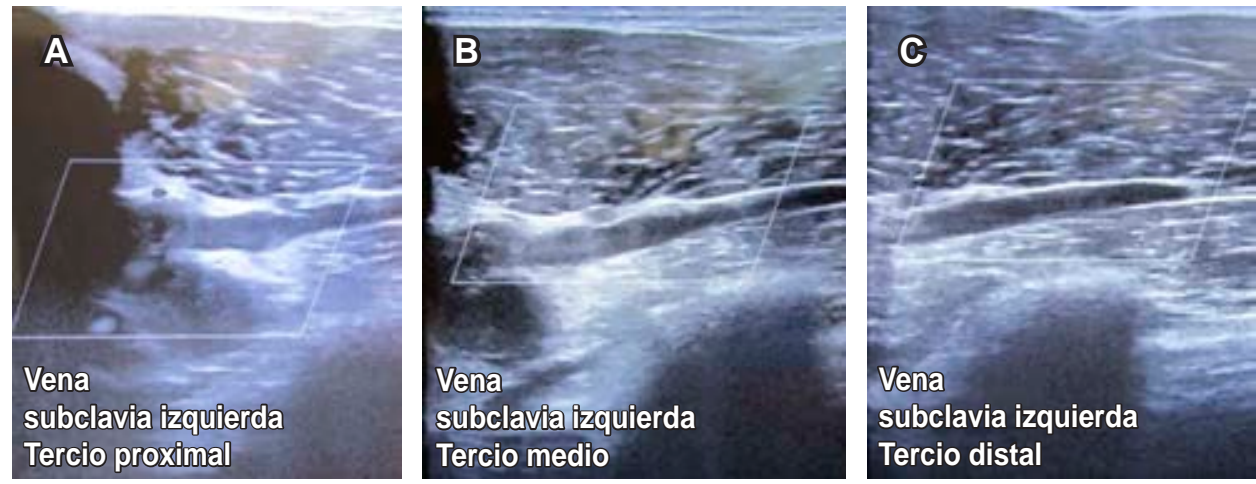

La trombosis venosa profunda (TVP) primaria de miembros superiores a nivel de las venas axilar-subclavia es una enfermedad rara, se le denomina síndrome de Paget-Schroetter, ${ }^{1,2}$ también conocida como trombosis de esfuerzo, ya que por lo general se presenta de manera repentina tras el desarrollo de una actividad vigorosa con la extremidad superior ${ }^{3}$ (como en el caso expuesto), representa aproximadamente de 1 a $4 \%$ de todos los casos de TVP. Su incidencia anual se estima de uno a dos/100,000 y ante sospecha diagnóstica, el estudio inicial de elección es el ultrasonido Doppler. ${ }^{4}$

\section{REFERENCIAS}

1. Marín C, Ferreiro L, Tejera A, Roca J. Trombosis venosa profunda primaria de miembro superior. Semergen. 2015; 41 (4): e15-e17.

2. Rosa Salazar V, Otálora Valderrama SP, Hernández Contreras ME, García Pérez B, Arroyo Tristán AA, García Méndez MM. Manejo multidisciplinar del síndrome de Paget-Schroetter. A propósito de una serie de 8 casos. Arch Bronconeumol. 2015; 51 (8): e41-e43. doi: 10.1016/j.arbres.2014.09.003.

3. Chu AS, Harkness J, Witmer CM. Spontaneous subclavian vein thrombosis in a healthy adolescent cheerleader: a case of paget-schroetter syndrome. Pediatr Emerg Care. 2017; 33 (10): e92-e94.

4. Jourdain V, Goldenberg WD, Matteucci M, Auten J. Paget-Schroetter syndrome: diagnostic limitations of imaging upper extremity deep vein thrombosis. Am J Emerg Med. 2016; 34 (3): 683.e1-3. doi: 10.1016/j.ajem.2015.07.018. 